\title{
Cenozoic structural and metamorphic evolution and geological map and sections of the NW Indian Himalaya
}

\author{
Albrecht Steck \\ Institut de Minéralogie et Géochimie, Universi té de Lausanne, BFSH-2, CH-1015 Lausanne, SWITZERLAND \\ For correspondence, E-mail: al brecht.steck@img.unil.ch
}

A multidisciplinary geological study of the Mandi-Leh transect through the NW Indian Himalaya has been performed since 25 years by geologists from Lausanne: Aymon Baud, Vincent Baudraz, Hugo Bucher, François Bussy, Mike Cosca, Pierre Dèzes, Jean-Luc Epard, Arthur Escher, Matthieu Girard, Henri Masson, Martin Robyr, Micha Schlup, Laurent Spring, Albrecht Steck, Edgar Stutz, Philippe Thélin, Jean-ClaudeVannay and Martin Wyss (References in Steck 2003). These systematic investigations have turned this region into one of the best known geological cross section of the Himalayan range. The outcrops are easily accessible at low altitude (1000- $6000 \mathrm{~m}$ ). TheBarrovian regional metamorphic overprint increases from unmetamorphic to amphibolite facies. These favourable conditions offer the opportunity to recognise the pre-
Himalayan stratigraphy, to decipher the structural and metamorphic history in great detail, to study the mechanisms of nappe formation, and to propose original models for the formation of the Cenozoic Himalayan range.

The palinspastic section of the $\mathrm{N}$ Indian passive margin before the formation of the Himalayan range is characterised by a continuous stratigraphic column of Proterozoic to Paleocene sediments, which are cross-cut by Ordovician, Carboniferous and Permian normal faults and magmatic rocks. A low angle unconformity at the base of the Ordovician Thaple conglomerates recorded a Kaledonian extensional tectonic event, which includes a block rotation. No Palaeozoic or Mesozoic compressional structures are recognised. The Himalayan range was formed during the Cenozoic continental

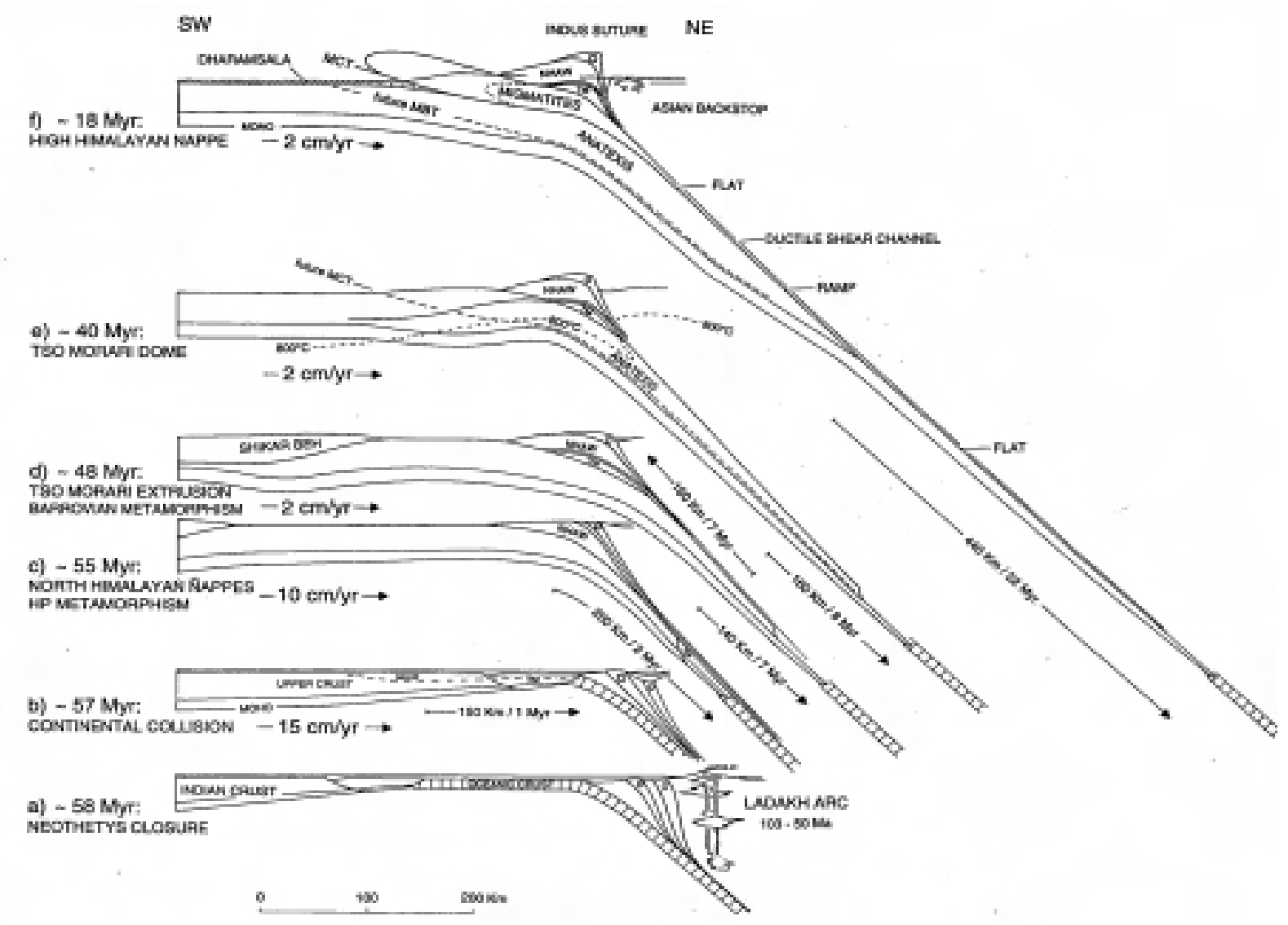

FIGURE 1. Development of the Cenozoic North and High Himalayan nappes (a) - (f). The proposed model is constrained by stratigraphic, structural, thermo-barometric, radiometric, data and rock physics considerations (J De Sigoyer et al. 2000, K Honegger et al. 1982, BK Mukherjee and HK Sachan 2001, RF Weinberg and WJ Dunlap 2000, A Steck 2003 and DL Turcotte and G Schubert 1982). Note that the unknown convergence velocity is assumed to decrease from a value of $\sim 15 \mathrm{~cm} / \mathrm{yr}$ before continental collision to a value of $\sim 2 \mathrm{~cm} / \mathrm{yr}$ during the Eocene and Miocene Himalayan range formation. 
collision by underthrusting of India below Asia by a typical succession of orogenic structures.

From $\mathrm{N}$ to $\mathrm{S}$, and hence from generally older to younger tectonic units, the following main tectonic domains are distinguished (Steck 2003):

1) The Late Cretaceous and PaleoceneTranshimalayan batholith and the Indus suturezone are composed of the 10350 Ma Ladakh arc magmatism (H onegger et al. 1982, Weinberg and Dunlap 2000), the accretion of the Dras-Nindam arc, the accretion and later obduction of the Spongtang immature island arc which formed the southern active border of Asia, and forearc sediment deposition. The Transhimalayan batholith, together with theAsian mantlewedge, represent the Asian backstop for the Himalayan range.

2) The Late Cretaceous-Neogene sediments of the Indus Group are deposited first in a forearc basin of the Ladakh batholith and then in an intermontane molasse basin, after the Early Eocene continental collision.

3) The Shikar Beh nappe is an intracontinental NEverging structure in the High Himalaya, of an unknown postLiassic, probably late Palaeocene to Eocene age.

4) The SW-directed North Himalayan nappe stack was created in Eocene time, along with the high pressure Tso Morari nappe, by ductile detachment of the Upper
Proterozoic-Early Eocene upper Indian crust during its underthrusting below Asia. The deformational structures of the North Himalayan Nappes confirm the thrust model of $E$ Argand (1916): Theimbricatestructure of the nappefronts are related to ductile shear zones in the root of the nappes. The Tso Morari nappe is composed of the mylonitic $479 \mathrm{Ma}$ (Steck 2003) Tso Morari granitewhich is crosscut by eclogitised mafic dikes. It has been extruded, pushed by buoyancy forces, after its burial to a depths of over $90 \mathrm{~km}$ ( crystallisation of coesite) some 55 Ma ago (DeSigoyer etal. 2000, Mukherjee and Sachan 2001). High water pressure in the zone of underthrusting derived from dehydration reactions in the subducted oceanic serpentinites may have assisted the Tso Morari granite mylonite detachment and buoyant extrusion by ductile flow and hydrofracturing.

5) The High Himalayan nappe or "Crystalline nappe", composed of Upper Proterozoic-Early Eocene was created in Eocene-Miocene time. The zone of dry intracrustal melting below the North Himalayan range and the Shikar Beh nappe stack determined the future position of the Main Central thrust at the base of the High Himalayan nappe. During under thrusting of the Indian lithosphere, the ductile and light upper Indian crust has been sheared off and extruded, pushed by buoyancy and compressional forces in the zone of plate collision (channel flow, Turcotte and Schubert 1982). The 22
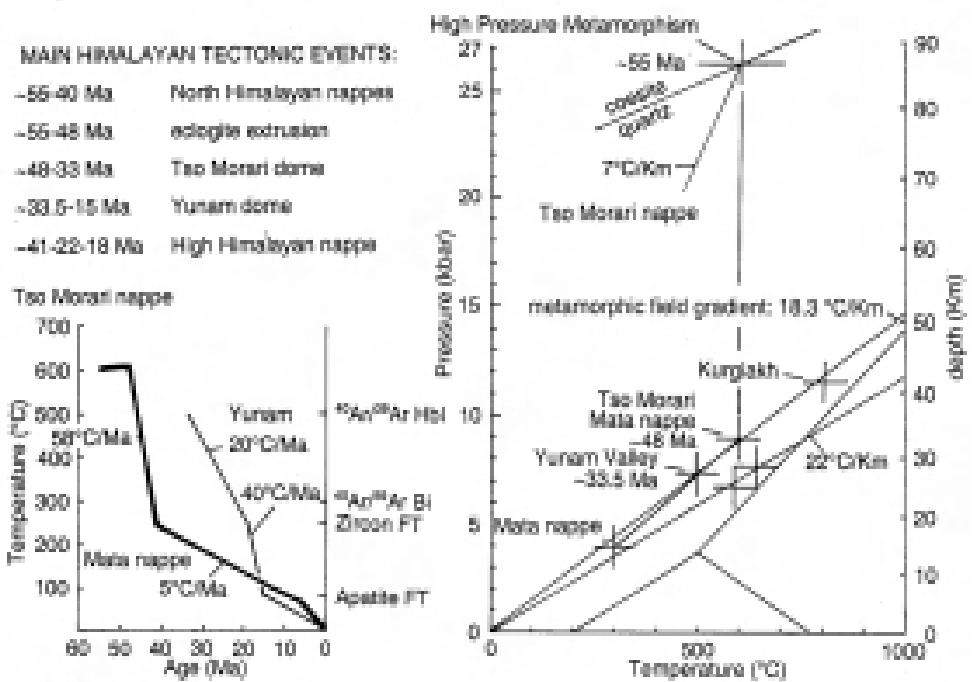

a) North Himalayan nappes
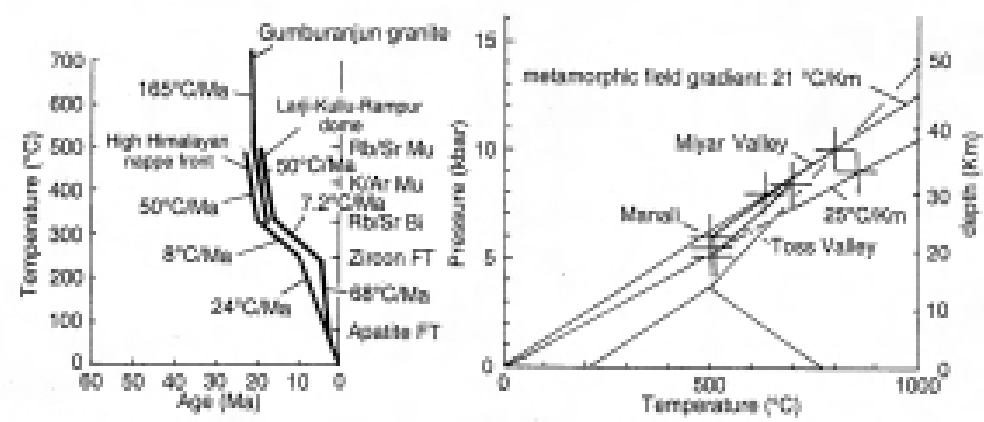

b) High Hmadayan negpe

FIGURE 2. Pressure-temperaure-time paths of the North and High Himalayan nappes. The fieldgradients of the Barrovian type orogenic metamorphism increase from $18-22^{\circ} \mathrm{C} / \mathrm{km}$ in the Eocene North Himalayan nappes to $21-25^{\circ} \mathrm{C} / \mathrm{km}$ in the Oligo-Miocene High Himalayan nappe (Epard et al. 1995, Sigoyer 2000, Dèzes et al 1999, Robyr et al. 2002, Schlup et al. 2003, Vannay and Grasemann 1998, Wyss et al. 1999, ref. in A Steck 2003). 
Ma Gumburanjun leucogranite, intruding the Zanskar extensional shear zone, testifie of the adiabatic muscowite dry melting in the preexisting prograde migmatites during the final extrusion of the High Himalayan nappe (Dèzes et al. 1999 in A Steck 2003).

6) The Lower Crystalline nappe, composed of lower Proterozoic rocks is characterised by an inverted metamorphic zonation similar to the High Himalayan nappe.

7) The Lesser Himalayan nappes, with formation of the deep-seated intracrustal Main Boundary Thrust, are formed from the late Miocene to the present, probably by a mechanism similar to the High Himalayan nappe formation.

8) Thin-skinned nappestructures that detach the up to $9 \mathrm{~km}$ thick Miocene to present Subhimalayan Molasse sediments of the Himalayan foredeep, characterise the Subhimalayan thrust which is related to the Active Himalayan thrust at the base of the present Himalayan accretionary wedge.

\section{References}

Argand E. 1916. Sur I'arc des Alpes occidentales. Eclogae geol Helv 14 145-191

DeSigoyer J, V Chavagnac, J Blichert-Toft, IM Villa, P Luais, S Guillot, M Cosca and G Mascle. 2000. Dating the Indian continental subduction and collisional thickening in the northwest Himalaya: Multichronology of the Tso Morari eclogites. Geology 28: 487-490

England PC and TJB Holland. 1979. Archimedes and the Tauern eclogites: the role of buoyancy in the preservation of exotic eclogitic blocks. EPSL 44: 287-294

Honeger K, V Dietrich, W Frank, A Gansser, M Thoeni and V Trommsdorff. 1982. Magmatism and metamorphism in the Ladakh Himalayas (the Indus-Tsangpo suture zone). Earth planet Sci Lett 60: 253-292

Mukherjee BK and HK Sachan. 2001. Discovery of coesite from Indian Himalaya: A record of ultra-high pressure metamorphism in Indian continental crust. Current Science 81: 1358-1361

Steck A. 2003. Geology of the NW Indian Himalaya. Eclogae Geol Helv 96: 147-196

Weinberg RF and WJ Dunlap. 2000. Growth and Deformation of the Ladakh batholith, Northwest Himalayas: Implication for timimg of continental collision and origin of calc-acaline batholiths. J Geol 108: $303-320$

Turcotte DL and G Schubert. 1982. Geodynamics. John Wiley \& Sons New York. $450 \mathrm{p}$ 